\title{
Monetary Actions, Total Spending and Prices
}

M ONETARY actions of the Federal Reserve System, which became less expansive last January and decidedly restrictive in June, continued in that restrictive stance through the end of 1969 . Changes in the rate of advance of total spending usually lag changes in monetary actions by two to three quarters, and the general level of prices tends to respond to changes in total spending with an additional lag of three or four quarters. According to this view of the channels and timing of the effect of stabilization actions, there has not been sufficient time for prices to respond significantly to the monetary actions that have been taken thus far. The only price effect has taken the form of a halt in the acceleration of prices.

\section{Monetary Actions}

The Federal Reserve System has restricted the growth of monetary aggregates in an attempt to slow the growth of total spending. The monetary base, a primary determinant of the money stock, increased at a 2.6 per cent rate from January to December after rising at a 6.4 per cent rate in the previous two years. Growth in the monetary base is determined largely by growth of Federal Reserve credit, which includes holdings of Treasury securities, loans, float, and other assets. Federal Reserve credit increased at a 4.7 per cent rate from January to December, after increasing at a 10 per cent rate in the previous two years. Member bank reserves available for private demand deposits declined at a 3.2 per cent annual rate from May to December, after remaining about unchanged earlier in the year and growing at a 5 per cent rate in 1967 and 1968.
The influence of monetary actions on the course of total spending may best be indicated by changes in the money stock, defined as demand deposits plus currency in the hands of the public, or by changes in the demand deposit component alone. Growth of the money stock has been restrained in 1969 by restricting the growth of Federal Reserve credit and member

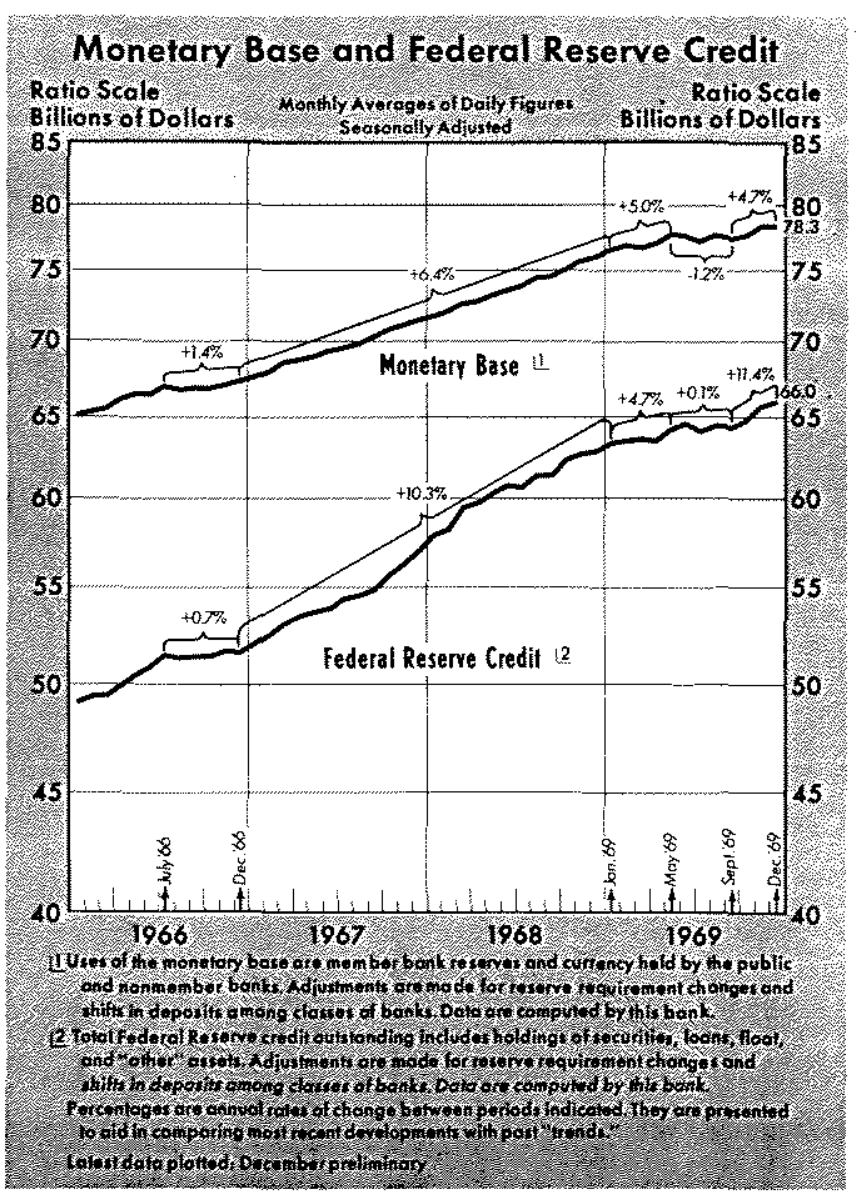


bank reserves. The money stock was about unchanged from June to December, after rising at a 4 per cent rate in the period from January to June and at a very rapid 7 per cent rate in 1967 and 1968.

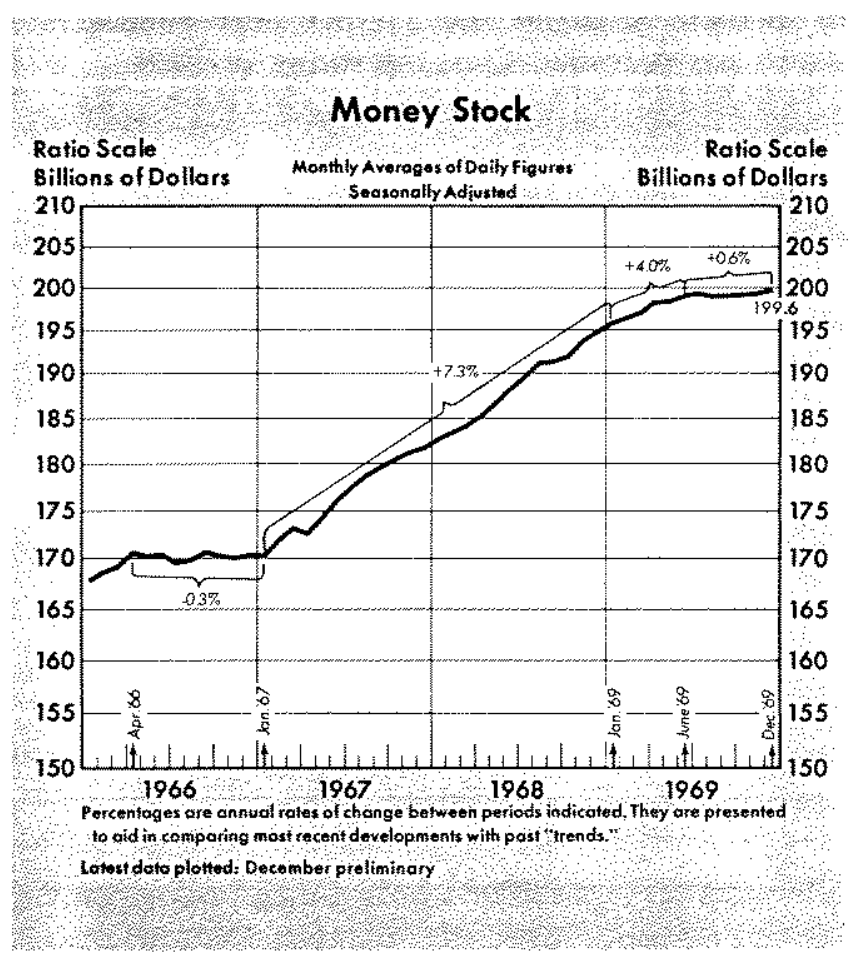

The money supply defined to also include commercial bank time deposits has shown an even slower growth trend in recent months. This broader concept of money declined at a 2.6 per cent annual rate from May to December, and was about unchanged in the first part of the year, after increasing at a 10 per cent rate in the previous two years.

This more marked change in trend of the broader money supply reflects primarily the erratic movements of time deposits to banks. Commercial banks are restricted by Federal Reserve Regulation $Q$ as to the maximum rates they can pay on various classes of time deposits. Since market yields on competitive assets, such as Treasury bills and commercial paper, have risen well above the ceiling rates on time deposits, banks have had difficulty attracting and retaining savings and other time deposits. Time deposit losses have been most pronounced with respect to large certificates of deposit. The amount of large CD's outstanding declined from $\$ 23.7$ billion in December 1968 to $\$ 11.1$ billion in December 1969. A moderate increase of other time deposits in the first half of the year was offset by losses in the last half. Total time deposits declined throughout the year, with the decrease totaling 5 per cent.

\section{Spending, Production and Employment}

Restrictive monetary actions in 1969 have begun to show their effects on the rate of advance of total spending. Estimates for the fourth quarter indicate that total spending (GNP) increased at a 5 per cent rate, compared with a 7.6 per cent advance in the previous year. Final sales, that is, spending other than for inventory accumulation, increased more than 8 per cent from mid-1968 to mid-1969, rose at a 6.3 per cent rate from the second to third quarter, and slowed further in the fourth quarter. Retail sales have been unchanged since last spring, compared with about a 5 per cent increase in the previous year.

In the typical response of spending and prices to changes in monetary actions, real product and employment growth are first affected, and prices only later. Since prices do not respond immediately, any slowing in total spending in response to restrictive monetary actions is reflected initially in a slowing of real product growth.

Real product growth is estimated to have been about unchanged from the third to the fourth quarter, after increasing 2.5 per cent in the previous year. Industrial production declined at a 6 per cent annual rate from July to November, after increasing 5.2 per cent in the previous year.

Associated with the decline in output growth, the rate of employment growth has been slowing. Payroll

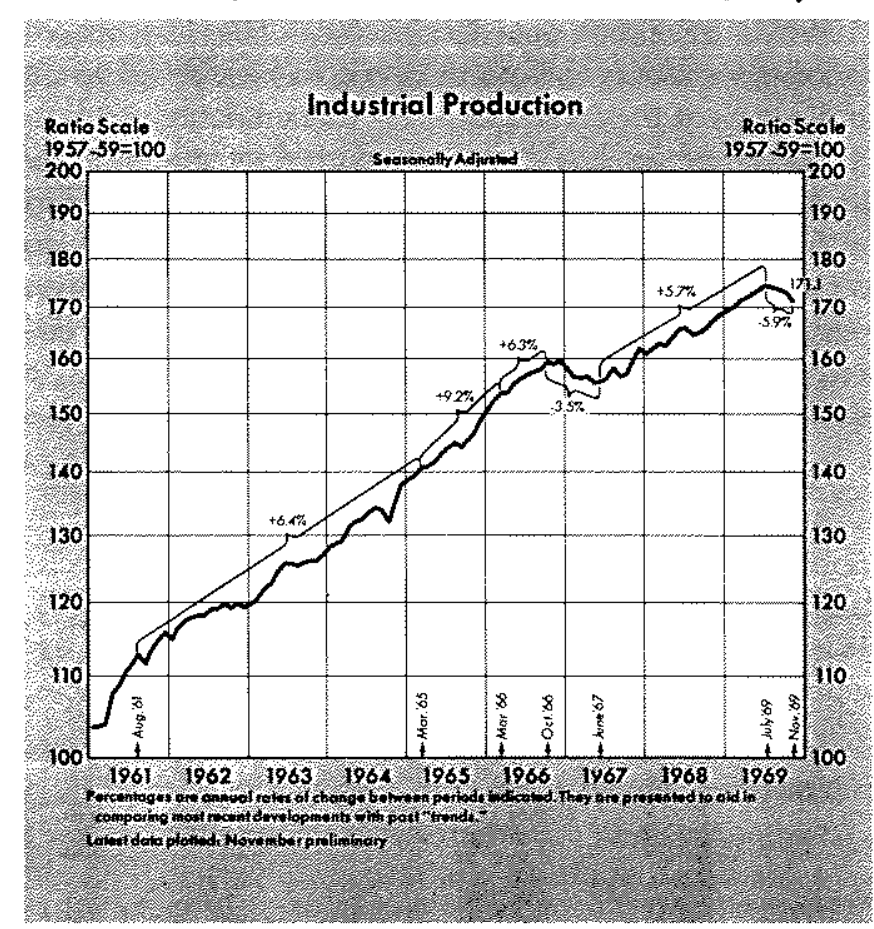




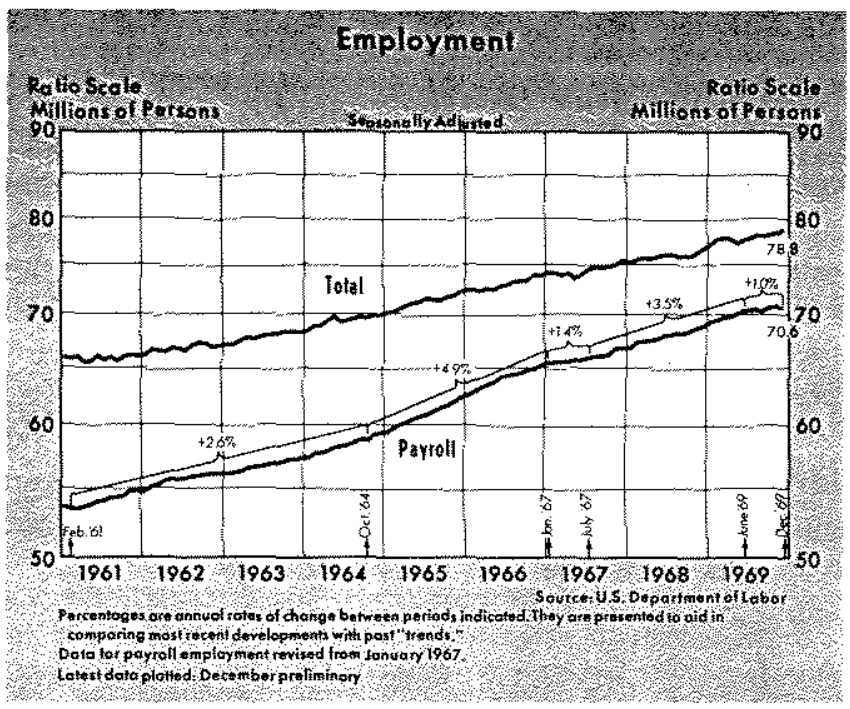

employment rose at about a 1 per cent annual rate in the last half of 1969 , compared with about a 3.5 per cent increase in the preceding twelve months. The slowing in the rate of growth of employment was not insignificant, but it probably understates the extent of the economic slowdown which has occurred. Many employers have retained workers in the face of declining growth of sales because of a belief that the overall slowdown in economic activity might be temporary and that the costs of training new personnel at a later date would be excessive.

\section{Prices}

Prices have not yet decelerated. The absence of price response at this point is not to be viewed as an indication of the failure of restrictive monetary actions. Total spending has just begun to slow significantly and, according to historical experience, prices should not be expected to decelerate significantly for another three or four quarters. In fact, there have been occasions in recent economic history when price increases accelerated temporarily in the face of a slowdown in real output.

Current indications are that prices have stopped accelerating, but this may not be permanent. It is possible that some further acceleration may occur before prices decelerate in late 1970 or early 1971. Wholesale prices of industrial commodities, which exclude the erratic movements of agricultural prices, have continued to rise at about the 4 per cent rate of the past year, compared with a 2.2 per cent rate in the preceding two years and a 0.4 per cent rate in the 1958-65 period. Consumer prices have continued to increase at about the 5.5 per cent annual rate which has prevailed since the spring of 1968 .

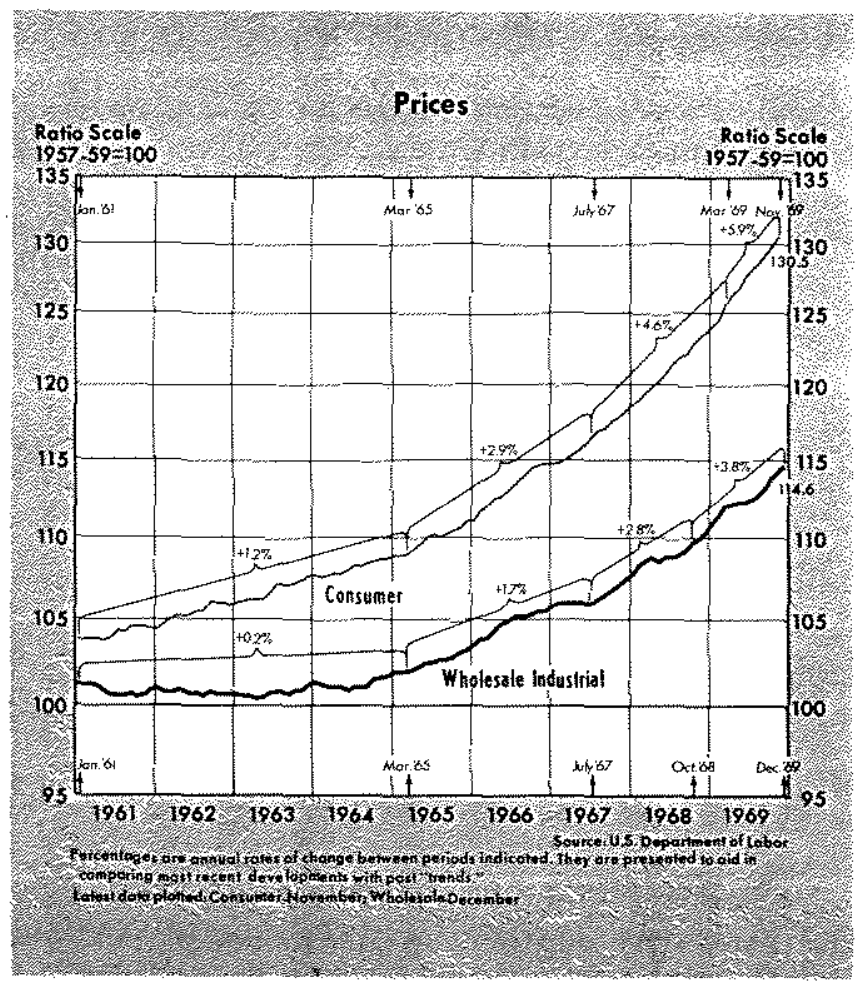

\section{Conclusion}

Monetary restraint has already acted to slow growth in spending, output and employment. Average prices, however, have continued to rise rapidly. The curtailment of total spending is expected to eventually slow price increases. The monetary authorities are confronted with the necessity of overcoming strong inflationary pressures without contributing immoderately to declines in real output. Restraint of monetary growth is providing a substantial dampening effect on total dollar spending and on real output, but upward price movements can be expected to moderate only gradually. Continued severe monetary restraint might be expeoted to reduce inflation more quickly but would also tend to cause immoderate slowing in output and employment growth, and restraint might consequently be reversed prematurely, as in 1967. 